\title{
Infections in severe alcoholic hepatitis
}

\author{
Eleni Karakike ${ }^{a}$, Christophe Moreno ${ }^{b, c}$, Thierry Gustot ${ }^{b, c, d}$
}

CHU Brugmann; C.U.B. Erasme, Université Libre de Bruxelles; Université Libre de Bruxelles, Brussels, Belgium; Centre de Recherche sur l'inflammation (CRI), Paris, France

\begin{abstract}
Severe alcoholic hepatitis ( $\mathrm{sAH}$ ), defined by a modified discriminant function $\geq 32$, is the most severe form of alcohol-induced liver disease and is associated with a 1-month mortality rate of around $30 \%$. Corticosteroid treatment remains the only therapeutic option that improves shortterm survival. Infectious complications, occurring in approximately $50 \%$ of patients, are the main causes of death, even in patients who benefit from corticosteroids. Liver failure, recent alcohol consumption and immunosuppressive drugs contribute to this infectious risk. Although infection is a well-described feature of cirrhosis, little is known about the characteristics of infections in sAH. Infection is mainly of bacterial origin and frequently affects the respiratory tract. Pathogens classically observed in cirrhosis, such as gram-negative bacilli, are frequently involved, but opportunistic pathogens, such as fungi (Aspergillus fumigatus, Pneumocystis jirovecii) or viruses (Cytomegalovirus, Herpes simplex) may appear, mainly related to corticosteroid treatment. A high level of suspicion with systematic screening and prompt, adequate treatment are warranted to improve outcomes in these patients. Prophylactic strategies in this high-risk population should be assessed in well-designed trials.
\end{abstract}

Keywords Alcoholic hepatitis, infection, corticosteroids, aspergillosis

Ann Gastroenterol 2017; 30 (1): 1-9

\section{Introduction}

Severe alcoholic hepatitis (sAH) is a clinical entity identified as the most severe form of alcoholic liver disease and presents high incidence rates among young people. The diagnosis of sAH requires a recent or ongoing excessive alcohol intake (minimal thresholds for women $\geq 40$ g per day [ 3 drinks], for men $\geq 50-60$ g per day [ 4 drinks]), recent onset ( $<3$ months) of severe jaundice (total bilirubin $\geq 5 \mathrm{mg} / \mathrm{dL}$ ) and ideally a liver biopsy showing typical histological lesions, macrovesicular steatosis with at least one of the following: ballooning

aDepartment of Infectious Diseases, CHU Brugmann (Eleni Karakike); ${ }^{b}$ Department of Gastroenterology and Hepato-Pancreatology, C.U.B. Erasme, Université Libre de Bruxelles (Christophe Moreno, Thierry Gustot); 'Laboratory of Experimental Gastroenterology, Université Libre de Bruxelles (Christophe Moreno, Thierry Gustot), Brussels, Belgium; 'Inserm Unité 1149, Centre de Recherche sur l'Inflammation (CRI), Paris, France (Thierry Gustot)

\section{Conflict of Interest: None}

Correspondence to: Thierry Gustot MD, PhD, Associate Professor, Director of the Liver Transplant Unit Department of Gastroenterology and Hepato-Pancreatology, C.U.B. Erasme, Université Libre de Bruxelles, Brussels, Belgium, Tel.: +32 25553714, Fax: +32 25554802, e-mail: thierry.gustot@erasme.ulb.ac.be

Received 17 August 2016; accepted 02 October 2016; published online 27 October 2016

DOI: https://doi.org/10.20524/aog.2016.0101 hepatocytes, Mallory-Denk bodies and neutrophil infiltration, and intrasinusoidal fibrosis [1]. The true prevalence of sAH is currently unknown, given the lack of systematic biopsy-driven diagnosis, but it has been reported to be as high as $20 \%$ in hospitalized alcoholic patients [2]. In Europe, a more recent Danish study over a decade found an incidence of nearly $40 / 10^{6}$ inhabitants per year [3]. In those population studies only clinical criteria were used, and the number of $\mathrm{AH}$ diagnoses may have been under- or overestimated. Severity stratification in $\mathrm{AH}$ is crucial, for prognostication as well as for treatment purposes; $\mathrm{sAH}$ is classically defined by a Maddrey (modified) discriminant function $(\mathrm{mDF})$ of $\geq 32$ and is associated with a poor prognosis (28-day and 1-year mortality rates $30 \%$ and $50 \%$, respectively) $[1,4,5]$.

Although the treatment for $\mathrm{AH}$ continues to be debated, corticosteroids (prednisone $40 \mathrm{mg}$ per day), the most widely used treatment, showed a $14 \%$ reduction in 1 -month mortality in $\mathrm{sAH}$ (defined by $\mathrm{mDF} \geq 32$ ) based on a metaanalysis of 5 randomized controlled trials (RCT) [4]. On the other hand, pentoxifylline, compared with placebo in a small trial, has shown encouraging results in reducing mortality, mainly by preventing hepatorenal syndrome [6]. Recently, a large-scale RCT (STOPAH) showed that corticosteroids significantly improved survival at 28 days when compared to placebo and after adjustment for different severity factors, whereas pentoxifylline had no significant effect. The survival benefit from corticosteroids was not maintained at 90 days or 1 year [7]. Although discrepancies persist, current guidelines 
recommend the use of corticosteroids in sAH, in the absence of contraindications such as uncontrolled infection, active gastrointestinal bleeding, or hepatorenal syndrome. The Lille score (freely available calculator on http://www. lillemodel.com/), assessing the response after seven days of corticosteroid treatment, offers an additional prognostication tool by identifying the subgroup of patients who will benefit from a 28-day corticosteroid treatment. Responders to corticosteroids, defined by a Lille score $<0.45$, have an excellent prognosis (85\% survival at 6 months), while non-responders (Lille score $\geq 0.45$ ), who represent nearly $40 \%$ of treated sAH patients, demonstrate substantially lower survival rates $(25 \%$ at 6 months) [8]. The cessation of corticosteroids is recommended in these non-responders after one week of treatment. Currently, no alternative therapeutic intervention has been effective in reducing mortality in non-responders. A multicenter study showed that highly selected transplanted non-responders had significantly higher 6-month survival rates than nonresponder controls ( $77 \%$ vs. $23 \%, \mathrm{P}<0.001)$ and similar ones to responders [9]. Considering that, using stringent criteria for patient selection, alcohol relapse occurred rarely and the donor pool was minimally affected, this strategy seems to be gaining ground worldwide.

\section{Infections in SAH}

Infection is one of the main complications of $\mathrm{sAH}$, as well as one of the major causes of mortality in this setting [3]. Infected patients with sAH suffer from a further increase in mortality of $30 \%$ at 2 months. Even responders to corticosteroids, in case of infection, present a survival similar to that of nonresponders [10].

Infections accounted for $24 \%$ of all deaths in the largest sAH trial to date [7]. In another study, which included 162 patients with $\mathrm{sAH}$, systemic inflammatory response syndrome (SIRS) at admission and in-hospital infection were independently associated with multiple organ failure, which in turn was associated with higher mortality, independently of different severity scores for liver dysfunction and responses to corticosteroids [11].

Reported mortality attributable to infection is probably underestimated, because even other causes of mortality in sAH, such as liver failure or related events and gastrointestinal bleeding, may be precipitated by or concomitant with an unidentified infection $[7,12]$.

\section{Incidence of infections in SAH}

The incidence of infections has been evaluated in previous therapeutic trials as part of the secondary outcomes or adverse events of the studied intervention. A meta-analysis of 12 randomized trials found a cumulative incidence of infection of $20 \%$ in patients with sAH during corticosteroid treatment (28-day follow up in 1062 patients without infection at baseline) [12]. The heterogeneity of these studies, though, prevents safe conclusions from being drawn.

Very few studies are designed to address the issue of infection in sAH in clinical practice. Louvet et al, in a cohort of 246 patients, found that $26 \%$ of patients presented an infection at the time of sAH diagnosis, while another $22 \%$ were infected during the 2-month period of follow up and treatment, for an overall incidence of infection of nearly $50 \%$ [10]. Michelena et al reported an incidence of 53\% in a cohort of 162 patients with biopsy-proven sAH during a 90-day follow up [11]. Finally, a study that included 79 patients with $\mathrm{sAH}$, followed up for 3 months in our institution, reported even higher rates of infection, which was present in $81 \%$ of cases, $37 \%$ of which were infected at admission [13]. Table 1 summarizes the reported incidences in different published cohorts with $\mathrm{sAH}$.

\section{Risk factors for infection in SAH}

\section{Liver-associated immunodeficiency}

The high incidence of infections may be partly explained by underlying cirrhosis, frequently present in biopsy-proven sAH (82-100\%)and cirrhosis-related defects in the immune system $[18,30]$. Cirrhosis-associated immune dysfunction (CAID) involves a state of immunodeficiency, and in parallel a state of persistent activation of the immune system cells, especially monocytes, with increased production of proinflammatory cytokines and SIRS [31]. CAID is a complex, multifactorial process, resulting from bacterial overgrowth, dysbiosis and increased translocation, which is responsible for continuous stimulation of immune system cells by microbialassociated molecular patterns and hypersplenism, and splenic pooling of immune system cells [32]. This continuous interaction of gut bacteria with the immune system may lead to exhaustion of the immune response and "immune paralysis". The immune dysfunction is present at multiple cell levels (neutrophils, monocytes, $\mathrm{T}$ and $\mathrm{B}$ lymphocytes and natural killers) and was recently reviewed by Albillos et al [33].

Superimposed sAH seems to worsen this cirrhosis-induced immunodeficiency. Compared to patients with advanced alcohol-related cirrhosis, sAH patients presented a more markedly immunosuppressive profile of T lymphocytes (higher interleukin-10 expression and lower interferon- $\gamma$ production) due to overexpression of inhibitory receptors (PD1, PDL1, TIM3 and galectin-9) and reduced neutrophil antimicrobial activities (phagocytosis and oxidative burst in response to Escherichia coli). These alterations seem to be dependent on the higher chronic lipopolysaccharide exposure observed in $\mathrm{sAH}$ [15]. Thus, it is reasonable to expect a higher incidence of infection in SAH than in cirrhosis. One study compared patients with $\mathrm{AH}$ (of whom $81 \%$ had $\mathrm{sAH}$ and were treated with pentoxifylline) to cirrhotic patients with equally severe disease (based on $\mathrm{mDF}$ ) and found a higher incidence of infectious episodes in the former group (38\% and 25\% respectively) [26]. Those data suggest that sAH patients, even more than cirrhotic 
Table 1 Incidence of infections in sAH

\begin{tabular}{|c|c|c|c|c|c|c|}
\hline Study & No. pts & $\begin{array}{c}\text { At baseline } \\
\%\end{array}$ & follow-up & $\begin{array}{l}\text { Follow-up } \\
\text { duration }\end{array}$ & $\begin{array}{l}\text { Sites (\% of all } \\
\text { infections) }\end{array}$ & $\begin{array}{l}\text { Severity } \\
\text { scores }\end{array}$ \\
\hline Thursz $2015[7]^{*},+$ & 1092 & $10 \%^{*}$ & $10 \%^{\S}$ & 12 months & $\begin{array}{c}\text { Pulm } 50 \%> \\
\text { SB } 25 \%>\text { SSTI } \\
5 \%>\text { UTI } 2 \%\end{array}$ & $\begin{array}{c}\mathrm{mDF} \\
62.6(\text { mean })\end{array}$ \\
\hline $\begin{array}{l}\text { Haim-Boukobza } \\
2015[14] \dagger\end{array}$ & 84 & N/A & $\begin{array}{c}38.1 \% \text { overall } \\
91 \% \text { bacterial } \\
9 \% \text { viral }\end{array}$ & $\begin{array}{c}\text { LOS } \\
\text { (non-specified) }\end{array}$ & N/A & $\begin{array}{c}\mathrm{mDF} \\
73.3 \text { (mean) }\end{array}$ \\
\hline $\begin{array}{l}\text { Michelena } \\
2015 \text { [11] }\end{array}$ & 162 & $\begin{array}{c}19.7 \% \\
\text { UTI } 31 \%> \\
\text { SB } 19 \%> \\
\text { SB P16\% > } \\
\text { Pulm 9\% }\end{array}$ & $33.3 \%$ & 3 months & $\begin{array}{c}\text { Pulm 27\% > } \\
\text { UTI } 24 \%> \\
\text { SBP } 11 \%\end{array}$ & $\begin{array}{c}\text { mDF } \\
43 \text { (mean) }\end{array}$ \\
\hline $\begin{array}{l}\text { Markwick } \\
2015 \text { [15] }\end{array}$ & 20 & N/A & $60 \%$ & 12 months & N/A & $\begin{array}{c}\mathrm{mDF} \\
55.4 \text { (mean) }\end{array}$ \\
\hline Park $2014[16]^{*}$ & 121 & $\mathrm{~N} / \mathrm{A} \ddagger$ & $8 \%$ & 6 months & N/A & $\begin{array}{c}\mathrm{mDF} \\
66.3 \text { (weighted } \\
\text { mean) }\end{array}$ \\
\hline $\begin{array}{l}\text { Wernlund } \\
2014 \text { [17] }\end{array}$ & $\begin{array}{c}32 \\
(\mathrm{AH}+\mathrm{sAH})\end{array}$ & 0 & $28 \%$ & 1 month & $\begin{array}{c}\text { Only BSI: SB } \\
33 \% \\
> \\
\text { UTI=CLABSI } \\
22 \% \\
>\text { Abdo=Pulm } \\
11 \%\end{array}$ & $\begin{array}{c}\mathrm{mDF} \\
76 \text { (mean) }\end{array}$ \\
\hline $\begin{array}{l}\text { Altamirano } \\
2014 \text { [18] }\end{array}$ & 121 & N/A & $39 \%$ & $\begin{array}{c}\text { LOS } \\
\text { (non-specified) }\end{array}$ & $\begin{array}{c}\text { Pulm } 26 \%> \\
\text { UTI } 23 \%> \\
\text { SSTI } 8 \%>\text { SBP } \\
6 \%\end{array}$ & $\begin{array}{c}\text { ABIC } \\
7.3 \text { (median) } \\
\text { MELD } \\
18 \text { (median) }\end{array}$ \\
\hline $\begin{array}{l}\text { Karakike } \\
2014 \text { [13] }\end{array}$ & 79 & $30 \%$ & $51 \%$ & 3 months & $\begin{array}{c}\text { Pulm } 40 \%> \\
\text { UTI } 16 \%> \\
\text { PB13\% > } \\
\text { SBP11\% > } \\
\text { SSTI } 9 \%\end{array}$ & $\begin{array}{c}\mathrm{mDF} \\
62(\text { median})\end{array}$ \\
\hline $\begin{array}{l}\text { Mathurin } \\
2013[19]^{*},+\end{array}$ & 270 & $\mathrm{~N} / \mathrm{A} \ddagger$ & $32.6 \%$ & 6 months & N/A & $\begin{array}{c}\mathrm{mDF} \\
56.5 \text { (weighted } \\
\text { mean) }\end{array}$ \\
\hline Sidhu $2012[20]^{*},+$ & 70 & $\mathrm{~N} / \mathrm{A} \ddagger$ & $33 \%$ & 6 months & SB (96\%) & $\begin{array}{c}\text { mDF } 76.7 \\
\text { (weighted } \\
\text { median) }\end{array}$ \\
\hline $\begin{array}{l}\text { Liangpunsakul } \\
2011[21]\end{array}$ & $56809(\mathrm{AH}+\mathrm{sAH})$ & $14 \%$ & N/A & $\begin{array}{c}\text { LOS } \\
(6.5 \pm 7.7 \text { days })\end{array}$ & $\begin{array}{l}\text { UTI } 68 \%> \\
\text { SB } 15 \%> \\
\text { SBP14\%> } \\
\text { Pulm } 2.9 \%\end{array}$ & $19 \% \mathrm{HE}+$ \\
\hline $\begin{array}{l}\text { Nguyen-Khac } \\
2011[22]^{*}\end{array}$ & 174 & $\mathrm{~N} / \mathrm{A} \ddagger$ & $30.5 \%$ & 6 months & $\begin{array}{c}\text { SBP } 26 \%> \\
\text { Pulm=UTI } \\
21 \%>\text { SB } 15 \% \\
>\text { SSTI } 6 \%\end{array}$ & $\begin{array}{c}\mathrm{mDF} \\
56.1 \text { (weighted } \\
\text { mean) }\end{array}$ \\
\hline $\begin{array}{l}\text { Moreno } 2010 \\
{[23]^{\star}}\end{array}$ & 47 & N/A & $36 \%$ & 1 month & N/A & $\begin{array}{l}\text { mDF } 52 \\
\text { (weighted } \\
\text { median) }\end{array}$ \\
\hline $\begin{array}{l}\text { Sharma } 2009 \\
{[24]^{*}}\end{array}$ & 19 & $\mathrm{~N} / \mathrm{A} \ddagger$ & $26 \%$ & 2 months & $\begin{array}{l}\text { Pulm } 60 \% \text {, } \\
\text { TB } 40 \%\end{array}$ & $\begin{array}{c}\mathrm{mDF} \\
66 \text { (median) }\end{array}$ \\
\hline De $2009[25]^{*,+}$ & 68 & $\mathrm{~N} / \mathrm{A} \ddagger$ & $14.7 \%$ & 12 months & N/A & $\begin{array}{c}\mathrm{mDF} \\
56 \text { (mean) }\end{array}$ \\
\hline
\end{tabular}

(Contd...) 
Table 1 (Continued)

\begin{tabular}{|c|c|c|c|c|c|c|}
\hline Study & No. pts & $\begin{array}{c}\text { At baseline } \\
\%\end{array}$ & $\begin{array}{l}\text { During follow } \\
\text { up }\end{array}$ & $\begin{array}{l}\text { Follow-up } \\
\text { duration }\end{array}$ & $\begin{array}{l}\text { Sites (\% of all } \\
\text { infections) }\end{array}$ & $\begin{array}{l}\text { Severity } \\
\text { scores }\end{array}$ \\
\hline Louvet 2009 [10] & 246 & $\begin{array}{c}25.6 \% \\
(\mathrm{SBP} / \mathrm{SB} \\
44 \%> \\
\text { UTI } 32 \%> \\
\text { Pulm 13\% } \\
>\text { SSTI } \\
11 \%)\end{array}$ & $23.2 \%$ & 2 months & $\begin{aligned} & \text { Pulm } 40 \% \\
> & \text { SBP } / \text { SB } 28 \% \\
> & \text { UTI } 18 \%> \\
& \text { SSTI } 14 \%\end{aligned}$ & $\begin{array}{c}\mathrm{mDF} \\
60.6 \text { (median) }\end{array}$ \\
\hline Verma 2006 [26] & $\begin{array}{c}99 \\
(\mathrm{AH}+\mathrm{sAH})\end{array}$ & N/A & $38 \%$ & 2 months & $\begin{array}{c}\text { UTI }=\text { SBP } 35 \% \\
>\text { Pulm } 20 \%> \\
\text { SB } 5 \%\end{array}$ & $\begin{array}{c}\text { mDF } \\
48 \text { (median) }\end{array}$ \\
\hline $\begin{array}{l}\text { Akriviadis } \\
2000[6]^{*},+\end{array}$ & 101 & $\mathrm{~N} / \mathrm{A} \ddagger$ & $12 \%$ & 1 month & $\begin{array}{l}\text { SBP 67\% > } \\
\text { Pulm 17\% }\end{array}$ & $\begin{array}{c}\mathrm{mDF} \\
45.6 \text { (weighted } \\
\text { mean) }\end{array}$ \\
\hline $\begin{array}{l}\text { Ramond } \\
1992[27]^{*},+\end{array}$ & 61 & $\mathrm{~N} / \mathrm{A} \ddagger$ & $23 \%$ & 2 months & $\begin{array}{l}\text { Pulm 31\% } \\
>\text { SBP 25\% > } \\
\quad \text { SB 13\% }\end{array}$ & $\begin{array}{c}\text { mDF } \\
55.3 \text { (weighted } \\
\text { mean) }\end{array}$ \\
\hline Minuk 1992 [28] & 97 & N/A & $\begin{array}{c}21 \% \\
\text { bacterial-culture } \\
\text { positive }\end{array}$ & N/A & $\begin{array}{c}\text { Pulm } 50 \%> \\
\text { UTI } 20 \%>\text { TB } \\
15 \%\end{array}$ & N/A \\
\hline $\begin{array}{l}\text { Theodossi } \\
1982[29]^{*},{ }^{\dagger}\end{array}$ & 55 & N/A & $24 \%$ & $\begin{array}{c}\text { LOS } \\
\text { (26 days) }\end{array}$ & SB $100 \%$ & $62 \% \mathrm{HE}+$ \\
\hline
\end{tabular}

* Therapeutic trial, $\dagger$ Infections were not part of primary or secondary outcome, $\ddagger$ Exclusion of non-controlled infections before randomization, $₫$ Listed as adverse events, so probably during follow up

Pts, patients; N/A, non-applicable; $m D F$, modified discriminant function; Pulm, pulmonary infection; SB, spontaneous bacteremia; SBP, spontaneous bacterial peritonitis; UTI, urinary tract infections; SSTI, skin and soft tissue Infections; Abdo, abdominal; TB, tuberculosis; BSI, bloodstream infections; CLABSI, central line-associated bloodstream infections; LOS, length of stay; AH, alcoholic hepatitis; sAH, severe alcoholic hepatitis; HE, hepatic encephalopathy; ABIC, age, bilirubin, international normalized ratio (INR) and creatinine score; MELD, model for end-stage liver disease

patients, are prone to infection, and a preemptive antibiotic strategy may be justified, if there is clinical suspicion.

\section{Infections related to immunosuppressive treatment}

A reasonable consideration is that corticosteroid treatment further increases the risk of infection; this is supported by some trials that evaluated corticosteroid treatment [7]. However, a recent network meta-analysis did not show a significant association between infection and either treatment (corticosteroids or pentoxifylline) compared to placebo [30]. Another meta-analysis focusing on corticosteroid treatment and infection found no difference between the corticosteroid and placebo arms in terms of bacterial infection occurrence or associated mortality [12]. Furthermore, it has been implied that development of infection depends more on the response to corticosteroid treatment (assessed by the Lille score) rather than the treatment per se or the treatment duration [10]. On the other hand, in the STOPAH trial, the administration of corticosteroids was associated with a greater incidence of infection (13\% vs. 7\%) [7]. It is of note that the frequency of opportunistic and invasive fungal infections increased among corticosteroid-treated patients [12,34]. The adjunction of $\mathrm{N}$-acetylcysteine to corticosteroid treatment has been shown to decrease the incidence of infections by $23 \%$, compared to corticosteroids alone, but without affecting lethal infections, which occurred equally in both groups [22]. The reason for this decrease is currently unknown.

Investigators explored the potential beneficial effect of specific tumor necrosis factor-a blockade in sAH. In both RCTs (one with infliximab in association with corticosteroids and the other with etanercept alone), the frequency of infections and the mortality rates were greater in the treatment arm compared with placebo $[35,36]$. This observation seems to be related to a worsening of immunodeficiency, as shown by an alteration in the activation capacity of circulating neutrophils.

\section{Diagnosis of infection}

Detecting infections in patients with $\mathrm{sAH}$ is challenging, because the SIRS criteria are met in approximately $50 \%$ of patients with sAH, whereas infection may be present in only one third of patients with SIRS and in as many as $10 \%$ of patients without [11]. Moreover, no clinical and biological parameters are able to distinguish between infected and non-infected patients [10]. C-reactive protein (CRP) and procalcitonin (PCT) levels have been useful for detecting infection in cirrhosis, but have demonstrated variable accuracies in distinguishing infection from SIRS without infection in AH. In a study by Kumar et al, CRP, with a cutoff level of $23 \mathrm{mg} / \mathrm{L}$, showed a sensitivity of $82 \%$ and a specificity 
of $75 \%$ in detecting infection, while the respective values for a PCT level of $0.57 \mathrm{ng} / \mathrm{mL}$ were $79 \%$ and $82 \%$ [37]. However, another study using the same PCT cutoff value failed to discriminate infected from non-infected patients [38]. In a larger trial, a PCT cutoff of $0.45 \mathrm{ng} / \mathrm{mL}$ had positive and negative predictive values of $83 \%$ and $71 \%$ respectively for infection-associated SIRS (negative predictive value increased to $79 \%$ if the cutoff level was lowered to $0.25 \mathrm{ng} / \mathrm{mL}$ ), while CRP displayed no discriminative capability [11]. In our opinion, these two parameters have a limited utility in clinical practice. Physicians should maintain a high level of suspicion for infection, even in the absence of SIRS or biological inflammatory markers. We recommend that screening exams (blood, urinary cultures, diagnostic paracentesis and chest $\mathrm{X}$-ray) be performed at the time of diagnosis and twice per week during hospitalization, or once weekly when the patient is discharged from hospital during the 28-day corticosteroid treatment.

\section{Bacterial infections}

The term "infection" is commonly used interchangeably with the term "bacterial infection". Indeed, bacterial infections represent the vast majority (86\%) of infectious episodes in the setting of sAH. Viral or fungal infections seem to represent $4 \%$ and $10 \%$ of all infections, respectively [13].

\section{Infectious sites}

Urinary tract infections (UTI) and respiratory infections seem to occur more commonly during $\mathrm{sAH}$, in contrast to cirrhosis, where spontaneous bacterial peritonitis (SBP) is predominant $[39,40]$. Michelena et al found UTI to be the most frequent (26\%), followed by respiratory infections (21\%), SBP (13\%) and spontaneous bacteremia (SB, 8\%) during a 90-day follow up [11].

Louvet et al distinguished infections at admission from those during treatment and follow up. At baseline, SBP or SB occurred more frequently (44\%), followed by UTI (32\%), respiratory (13\%) and cutaneous (11\%) infectious episodes. After or during corticosteroid treatment, a shift towards respiratory infections was noted ( $40 \%$ of all episodes), but SBP or SB (28\%) and UTI (18\%) decreased, while cutaneous infections remained stable (14\%) [10]. Concerning in-hospital infections only, Altamirano et al reported pneumonia as being the most frequent (26\%), followed by UTI (23\%), and skin and soft tissue infection (SSTI, 8\%), while SBP was present only in $6 \%$ of infected patients [18]. Similarly, in a metaanalysis of pooled data from 12 randomized trials evaluating corticosteroids, in-hospital infections during follow up (after exclusion of patients infected at baseline) occurred as follows: pneumonia in $23 \%$; UTI in $10 \%$; SBP in $7 \%$; and SSTI in $2 \%$ [12]. In our institution, pneumonia was present in $40 \%$; UTI in $16 \%$; SBP in $13 \%$; SB in $11 \%$; and SSTI in $9 \%$ of 95 bacterial infections [13]. Interestingly, the STOPAH trial also found a high prevalence of respiratory infections, representing $50 \%$ of all infections during follow up [7]. A possible interpretation for this shift from spontaneous infections, frequently seen as a hallmark of cirrhosis, towards respiratory infections, may be corticosteroid treatment, nosocomial origin and intensive care unit admission.

\section{Bacterial pathogens}

Data regarding pathogens are scarce in sAH studies and are mainly extrapolated from the literature on cirrhotic patients. Briefly, in cirrhosis, Gram-negative bacilli (GNB) are isolated in $30-70 \%$ of culture-positive infections and Escherichia coli (E. coli) is the most represented microorganism. However, Gram-positive cocci (GPC) (i.e. Enterococcus faecalis and Staphylococcus aureus [S. aureus]) emerge as the main bacteria isolated in nosocomial infections, and invasive procedures or admission to the intensive care unit (ICU) increase their isolation [41]. In a large international pointprevalence study on cirrhotic patients admitted to ICU, the most frequently isolated bacteria was $S$. aureus [42]. Moreover, multiresistant bacteria (extended-spectrum $\beta$-lactamase-producing Enterobacteriaceae, Pseudomonas aeruginosa, methicillin-resistant $S$. aureus, and Enterococcus faecium) become an emergent problem, mainly due to hospitalization, long-term norfloxacin prophylaxis and the wide use of $\beta$-lactams [39].

In a small specific study on $\mathrm{AH}, \mathrm{GNB}$, mainly E. coli, represented $75 \%$ of all isolated bacteria, as in cirrhotic patients without $\mathrm{AH}$ [26]. In our experience, we observed 67\% GNB and $29 \%$ GPC out of all bacterial pathogens, E. coli being the most frequently isolated organism (33\%), followed by S. aureus (17\%) [13]. On the other hand, another small study, focusing on bloodstream infections only, found a significant prevalence of GPC (44\%), while GNB were present in only $22 \%$ [17]. Specific pathogens may arise more frequently in the setting of AH. According to a large United States database, Clostridium difficile infection, among patients with $\mathrm{AH}$ followed up during hospitalization, had a prevalence of $1.6 \%$, which was 1.5-fold higher than that of hospitalized patients without $\mathrm{AH}$ and was associated with increased inpatient mortality [43].

\section{Fungal infections}

Fungal disease commonly occurs in immunocompromised individuals. Little is known about the incidence and impact of invasive fungal infection (IFI) in cirrhosis and even less in sAH. In the ICU, cirrhosis seems to be associated with higher fungal colonization and IFI [44]. The rate of fungal colonization reaches $25 \%$ in critically ill cirrhotic patients [42]. In one report, the presence of hepatic encephalopathy, concomitant bacterial infection, and a platelet count higher than $150,000 / \mathrm{mm}^{3}$ are independent predictors of IFI in sAH [45]. 


\section{Invasive aspergillosis (IA)}

Liver insufficiency has been suggested as a contributing factor in IA. Indeed, some cases, often with a fatal issue, have been observed in patients with decompensated cirrhosis or acute liver failure $[46,47]$. In those reports, the occurrence of IA was frequently associated with the use of corticosteroids. We previously reported an IA incidence of $16 \%$ in a prospective cohort of 94 patients with biopsy-proven sAH [34]. Risk factors for acquisition of IA were ICU admission and baseline model for end-stage liver disease score $\geq 24$, and the diagnosis is made after 6-80 days from corticosteroid initiation (median of 25 days). The sites of IA were the lungs, in the majority of cases, and the brain. The diagnosis of IA in sAH remains challenging. Indeed, radiological imaging of pulmonary IA revealed mainly non-specific lung infiltrates on chest CT and more rarely (in only $36 \%$ of the cases) multiple excavated nodules or "classical" condensations with a halo sign. Serum galactomannan (GM) may be a good screening test for IA in severe AH. In our experience, the classical cutoff $\geq 0.5$ for serum GM had a high diagnostic performance, with sensitivity $89 \%$, specificity $84 \%$, positive predictive value $67 \%$, and negative predictive value $95 \%$. This accuracy seems to be questionable, because lower sensitivity and specificity were reported in another context [48]. Diagnosis of IA depends on the intensity of the screening protocol (frequent GM testing, chest and cerebral CT, bronchoalveolar lavage). To adequately screen for IA, we recommend that a serum GM and chest X-ray be performed twice a week during corticosteroid treatment. Despite this aggressive screening, sAH complicated by IA was associated with a dramatically poor outcome. Like others, we observed a $100 \%$ transplant-free mortality rate in our study despite adequate antifungal treatment.

\section{Pneumocystis pneumonia}

Sporadic reports have associated sAH and concomitant corticosteroid use with Pneumocystis jirovecii pneumonia (PCP), with a $100 \%$ case-fatality rate [49-51]. In our cohort, PCP was suspected in $8 \%$ of our patients who were positive by polymerase chain reaction testing of bronchoalveolar lavage samples but were negative by direct examination (Giemsa staining) [34]. The distinction between colonization and symptomatic infection was difficult to make, because of the patients' poor general condition and the non-specific CT scan lung lesions.

\section{Invasive candidiasis}

The rate of diagnosis of invasive candidiasis, mainly candidemia, in sAH varies between 2 and $8 \%$ [34,45]. In our cohort, we observed 2 cases of candidemia with Candida glabrata, both with fatal outcomes. One small report described one patient with sAH and candidemia who survived, among 3 patients with this complication [52].

\section{Others}

Some reports isolated cases of mucormycosis, cryptococcosis and fusariosis in $\mathrm{sAH}[45]$.

\section{Viral infections}

\section{Hepatitis C virus (HCV)}

$\mathrm{HCV}$, unlike hepatitis B virus (HBV), is frequently associated with alcohol abuse [53]. The prevalence of antiHCV antibodies in AH reached 25\% in an analysis of pooled homogeneous data from 10 studies, while HCV RNA was present in $21 \%$ of cases in 4 of those studies [54]. In the United States, the prevalence of $\mathrm{HCV}$ in $\mathrm{AH}$ was $8 \%$, based on the Nationwide Inpatient Sample dataset of 2007 [55]. It has been suggested that HCV might be an additional independent risk factor for mortality, possibly because of the synergistic hepatotoxic effect and more advanced liver disease [56]. The specific aspects of the treatment of $\mathrm{AH}$ in the setting of concomitant HCV infection are currently unknown, because this group of patients was excluded from most therapeutic clinical trials (on corticosteroids or pentoxifylline), because of concerns about an enhancing effect on viral replication. In other contexts, e.g. after liver transplantation, corticosteroids are known to increase the replication of HCV and to accelerate the progression of liver fibrosis. In patients with $\mathrm{sAH}$ there are insufficient data to form a conclusion. Currently, HCV replication is not considered as a contraindication for corticosteroids. Based on a large survey, $75 \%$ of physicians did not change their approach for the treatment of $\mathrm{AH}$ if $\mathrm{HCV}$ was present [57]. Given the severity of sAH, we must frequently wait for an improvement in liver function before starting direct-acting agents against $\mathrm{HCV}$.

\section{HBV}

The natural course of HBV infection is determined through the interplay between viral replication and the host's immune reaction. Immunosuppressive treatments are able to induce $\mathrm{HBV}$ reactivation and a flare of their $\mathrm{HBV}$-related liver disease, leading, in some cases, to acute liver failure and death. HbsAgpositive patients, who must receive prednisone $40 \mathrm{mg}$ per day for 28 days, are considered at high risk of reactivation (11-20\%) [58,59]. In this case, it is recommended to start an antiviral agent (ideally tenofovir or entecavir) before initiating corticosteroids. On the other hand, HbsAg-negative antiHbc-positive patients on corticosteroids are at low risk of reactivation $(<1 \%)$. Here, it is recommended to monitor HBV DNA and to treat when a reactivation is observed.

\section{Hepatitis E virus (HEV)}

$\mathrm{HEV}$ is causing increasing concern as a cause of rapid decompensation and death in cirrhotic patients [60]. In one report 
Table 2 Proposed diagnostic checklist in sAH

\begin{tabular}{ll}
\hline At baseline (sAH diagnosis) & During follow up (28-day corticosteroids course) \\
\hline Blood, urinary and ascitic fluid cultures & Blood, urinary and ascitic fluid cultures (2/week) \\
Chest X-ray (if abnormalities, chest CT and BAL $\left.{ }^{*}\right)$ & $\begin{array}{l}\text { Chest X-ray (if abnormalities, chest CT and BAL) (2/week) } \\
\text { In case of pulmonary symptoms, chest CT }\end{array}$ \\
$\begin{array}{ll}\text { HCV, HBV (Hbs-Ag and anti-Hbc), (HEV) and CMV serologies } \\
\text { Serum galactomannan }\end{array}$ & $\begin{array}{l}\text { Serum galactomannan (2/week) } \\
\text { In case of neurological deterioration, brain CT (or better MRI) and } \\
\text { potentially CSF puncture }\end{array}$ \\
\hline
\end{tabular}

${ }^{*}$ In BAL, the following exams should be performed: direct microscopic examination, Giemsa coloration or immunofluorescence for Pneumocystis jirovecii, bacterial and fungal cultures, galactomannan, PCR for Pneumocystis jirovecii, cytomegalovirus and herpes simplex virus. Mycobacterial cultures should also be considered according to epidemiological setting

sAH, severe alcoholic hepatitis; CT, computed tomodensitometry; BAL, bronchoalveolar lavage; PCR, polymerase chain reaction; MRI, magnetic resonance imaging; CSF, cerebrospinal fluid

of 93 patients with sAH, 6\% patients had serologic evidence of acute HEV and $12 \%$ of past HEV. In this report, acute infection showed no impact on outcome, response to corticosteroids, or the need for liver transplantation [61]. Another team reported 4\% seroprevalence of acute HEV infection among 84 patients with sAH. The number of patients was too low to draw conclusions concerning the impact on disease course, but total bilirubin and creatinine levels were higher in those patients. Corticosteroids were not contraindicated in acute HEV, and no chronic HEV infection developed after immunosuppression [14].

\section{Others}

$\mathrm{AH}$ has been associated with sporadic cases of cytomegalovirus pneumonia. 7 cases have been reported, 5 of them concomitantly with PCP, with fatal outcomes [49-51]. Herpes simplex virus pneumonia has also been reported in 3 cases $[62,63]$. Data remain indicative, but considering the diagnostic challenges of cytomegalovirus pneumonia, its occurrence may be largely underestimated, highlighting the need for systematic assessment of infections in sAH.

\section{Concluding remarks}

Patients with sAH are prone to infections, especially of bacterial origin, which are present in $30-80 \%$ of cases. A high level of suspicion should be maintained with regard to all admitted patients with a diagnosis of sAH, as SIRS criteria and acute phase proteins are not accurate diagnostic markers for infection. Systematic screening is warranted, including at least blood, urine and ascitic fluid cultures, chest radiography, and other specimens according to clinical suspicion. The control of infection is mandatory before the start of corticosteroids and, in the case of resolution, infection does not impact the patients' outcomes. Under corticosteroids, patients with sAH who develop infections, mainly pneumonia, present a dramatic worsening of prognosis. It is unclear whether corticosteroids, or essentially liver dysfunction, are responsible for an increased risk of bacterial infections. However, opportunistic infections, including invasive aspergillosis, PCP, invasive candidiasis, and cytomegalovirus infection, become emergent problems in $\mathrm{sAH}$ related to immunosuppressive treatment. A prompt aggressive diagnostic strategy is needed to reveal these opportunistic infections, which are currently associated with a mortality rate of nearly $100 \%$. Thus, we propose a diagnostic checklist at baseline and during the follow-up period to improve the detection rate of these infectious complications (Table 2) and potentially the outcome. Given the high risk of infections in sAH, preemptive antibiotic treatment is started in most cases. Reassessment and antibiotic de-escalation or cessation at 48-72 h should be part of routine practice, to avoid unnecessary exposure to broadspectrum antibiotics and the risk of occurrence of infections due to multidrug-resistant pathogens, fungi or Clostridium difficile. Currently, the place of prophylaxis against bacteria, fungi or virus in sAH (particularly during immunosuppressive treatment) is unknown and should be assessed in well-designed trials.

\section{References}

1. Lucey MR, Mathurin P, Morgan TR. Alcoholic hepatitis. N Engl J Med 2009;360:2758-2769.

2. O'Shea RS, Dasarathy S, McCullough AJ; Practice Parameters Committee of the American College of Gastroenterology. Alcoholic liver disease. Hepatology 2010;51:307-328.

3. Orntoft NW, Sandahl TD, Jepsen P, Vilstrup H. Short-term and long-term causes of death in patients with alcoholic hepatitis in Denmark. Clin Gastroenterol Hepatol 2014;12:1739-1744.e1.

4. Mathurin P, O'Grady J, Carithers RL, et al. Corticosteroids improve short-term survival in patients with severe alcoholic hepatitis: meta-analysis of individual patient data. Gut 2011;60:255-260.

5. Mathurin P, Duchatelle V, Ramond MJ, et al. Survival and prognostic factors in patients with severe alcoholic hepatitis treated with prednisolone. Gastroenterology 1996;110:1847-1853.

6. Akriviadis E, Botla R, Briggs W, Han S, Reynolds T, Shakil O. Pentoxifylline improves short-term survival in severe acute alcoholic hepatitis: a double-blind, placebo-controlled trial. Gastroenterology 2000;119:1637-1648.

7. Thursz MR, Richardson P, Allison M, et al; STOPAH Trial. Prednisolone or pentoxifylline for alcoholic hepatitis. N Engl J Med 2015;372:1619-1628.

8. Louvet A, Naveau S, Abdelnour M, et al. The Lille model: a new tool 
for therapeutic strategy in patients with severe alcoholic hepatitis treated with steroids. Hepatology 2007;45:1348-1354.

9. Mathurin P, Moreno C, Samuel D, et al. Early liver transplantation for severe alcoholic hepatitis. N Engl J Med 2011;365:1790-1800.

10. Louvet A, Wartel F, Castel H, et al. Infection in patients with severe alcoholic hepatitis treated with steroids: early response to therapy is the key factor. Gastroenterology 2009;137:541-548.

11. Michelena J, Altamirano J, Abraldes JG, et al. Systemic inflammatory response and serum lipopolysaccharide levels predict multiple organ failure and death in alcoholic hepatitis. Hepatology 2015;62:762-772.

12. Hmoud BS, Patel K, Bataller R, Singal AK. Corticosteroids and occurrence of and mortality from infections in severe alcoholic hepatitis: a meta-analysis of randomized trials. Liver Int 2016;36:721-728.

13. Karakike E, Trepo E, Hites M, et al. Infections in patients with severe alcoholic hepatitis: a cohort study. ESCMID 2015, Copenhagen, Denmark.

14. Haim-Boukobza S, Coilly A, Sebagh M, et al. Hepatitis E infection in patients with severe acute alcoholic hepatitis. Liver Int 2015;35:870-875.

15. Markwick LJ, Riva A, Ryan JM, et al. Blockade of PD1 and TIM3 restores innate and adaptive immunity in patients with acute alcoholic hepatitis. Gastroenterology 2015;148:590-602.

16. Park SH, Kim DJ, Kim YS, et al; Korean Association for the Study of the Liver (KASL)-Alcohol Related Problems Study Group. Pentoxifylline vs. corticosteroid to treat severe alcoholic hepatitis: a randomised, non-inferiority, open trial. J Hepatol 2014;61:792-798.

17. Wernlund PG, Støy S, Lemming L, Vilstrup H, Sandahl TD. Blood culture-positive infections in patients with alcoholic hepatitis. Scand J Infect Dis 2014;46:902-905.

18. Altamirano J, Miquel R, Katoonizadeh A, et al. A histologic scoring system for prognosis of patients with alcoholic hepatitis. Gastroenterology 2014;146:1231-1239.e1-e6.

19. Mathurin P, Louvet A, Duhamel A, et al. Prednisolone with vs without pentoxifylline and survival of patients with severe alcoholic hepatitis: a randomized clinical trial. JAMA 2013;310:1033-1041.

20. Sidhu SS, Goyal O, Singla P, et al. Corticosteroid plus pentoxifylline is not better than corticosteroid alone for improving survival in severe alcoholic hepatitis (COPE trial). Dig Dis Sci 2012;57:1664-1671.

21. Liangpunsakul S. Clinical characteristics and mortality of hospitalized alcoholic hepatitis patients in the United States. J Clin Gastroenterol 2011;45:714-719.

22. Nguyen-Khac E, Thevenot T, Piquet MA, et al; AAH-NAC Study Group. Glucocorticoids plus N-acetylcysteine in severe alcoholic hepatitis. N Engl J Med 2011;365:1781-1789.

23. Moreno C, Langlet P, Hittelet A, et al. Enteral nutrition with or without $\mathrm{N}$-acetylcysteine in the treatment of severe acute alcoholic hepatitis: a randomized multicenter controlled trial. $J$ Hepatol 2010;53:1117-1122.

24. Sharma P, Kumar A, Sharma BC, Sarin SK. Infliximab monotherapy for severe alcoholic hepatitis and predictors of survival: an open label trial. J Hepatol 2009;50:584-591.

25. De BK, Gangopadhyay S, Dutta D, Baksi SD, Pani A, Ghosh P. Pentoxifylline versus prednisolone for severe alcoholic hepatitis: a randomized controlled trial. World J Gastroenterol 2009;15:1613-1619.

26. Verma S, Ajudia K, Mendler M, Redeker A. Prevalence of septic events, type 1 hepatorenal syndrome, and mortality in severe alcoholic hepatitis and utility of discriminant function and MELD score in predicting these adverse events. Dig Dis Sci 2006;51:1637-1643.

27. Ramond MJ, Poynard T, Rueff B, et al. A randomized trial of prednisolone in patients with severe alcoholic hepatitis. $N$ Engl J Med 1992;326:507-512.

28. Minuk G, Cohen A, Thompson V. Differences between infected and noninfected patients with acute alcoholic hepatitis. Can J Infect Dis 1992;3:240-242.

29. Theodossi A, Eddleston AL, Williams R. Controlled trial of methylprednisolone therapy in severe acute alcoholic hepatitis. Gut 1982;23:75-79.

30. Singh S, Murad MH, Chandar AK, et al. Comparative effectiveness of pharmacological interventions for severe alcoholic hepatitis: a systematic review and network meta-analysis. Gastroenterology 2015;149:958-970.e12.

31. Coant N, Simon-Rudler M, Gustot T, et al. Glycogen synthase kinase 3 involvement in the excessive proinflammatory response to LPS in patients with decompensated cirrhosis. I Hepatol 2011;55:784-793.

32. Wiest R, Garcia-Tsao G. Bacterial translocation (BT) in cirrhosis. Hepatology 2005;41:422-433.

33. Albillos A, Lario M, Álvarez-Mon M. Cirrhosis-associated immune dysfunction: distinctive features and clinical relevance. J Hepatol 2014;61:1385-1396.

34. Gustot T, Maillart E, Bocci M, et al. Invasive aspergillosis in patients with severe alcoholic hepatitis. J Hepatol 2014;60:267-274.

35. Naveau S, Chollet-Martin S, Dharancy S, et al; Foie-Alcool group of the Association Française pour l'Etude du Foie. A doubleblind randomized controlled trial of infliximab associated with prednisolone in acute alcoholic hepatitis. Hepatology 2004;39:1390-1397.

36. Boetticher NC, Peine CJ, Kwo P, et al. A randomized, doubleblinded, placebo-controlled multicenter trial of etanercept in the treatment of alcoholic hepatitis. Gastroenterology 2008;135:1953-1960.

37. Kumar K, Mohindra S, Raj M, Choudhuri G. Procalcitonin as a marker of sepsis in alcoholic hepatitis. Hepatol Int 2014;8:436-442.

38. Elefsiniotis IS, Skounakis M, Vezali E, et al. Clinical significance of serum procalcitonin levels in patients with acute or chronic liver disease. Eur J Gastroenterol Hepatol 2006;18:525-530.

39. Fernández J, Acevedo J, Castro M, et al. Prevalence and risk factors of infections by multiresistant bacteria in cirrhosis: a prospective study. Hepatology 2012;55:1551-1561.

40. Bajaj JS, O'Leary JG, Reddy KR, et al; NACSELD. Second infections independently increase mortality in hospitalized patients with cirrhosis: the North American consortium for the study of end-stage liver disease (NACSELD) experience. Hepatology 2012;56:2328-2335.

41. Fernández J, Navasa M, Gómez J, et al. Bacterial infections in cirrhosis: epidemiological changes with invasive procedures and norfloxacin prophylaxis. Hepatology 2002;35:140-148.

42. Gustot T, Felleiter P, Pickkers P, et al; EPIC II Group of Investigators. Impact of infection on the prognosis of critically ill cirrhotic patients: results from a large worldwide study. Liver Int 2014;34:1496-1503.

43. Sundaram V, May FP, Manne V, Saab S. Effects of Clostridium difficile infection in patients with alcoholic hepatitis. Clin Gastroenterol Hepatol 2014;12:1745-1752.e2.

44. Theocharidou E, Agarwal B, Jeffrey G, et al. Early invasive fungal infections and colonization in patients with cirrhosis admitted to the intensive care unit. Clin Microbiol Infect 2016;22:189.e1-e7.

45. Mogavero G, Delvart V, Coilly A, et al. Invasive fungal infections (IFI) in patients with severe acute alcoholic hepatitis $(\mathrm{AAH})$ : risk assessment and predictive factors. Hepatology 2012;56(Suppl 4):1109A.

46. Prodanovic H, Cracco C, Massard J, et al. Invasive pulmonary aspergillosis in patients with decompensated cirrhosis: case series. BMC Gastroenterol 2007;7:2. 
47. Falcone M, Massetti AP, Russo A, Vullo V, Venditti M. Invasive aspergillosis in patients with liver disease. Med Mycol 2011;49:406-413.

48. Singh N, Winston DJ, Limaye AP, et al. Performance characteristics of galactomannan and $\beta$-d-glucan in high-risk liver transplant recipients. Transplantation 2015;99:2543-2550.

49. Ichai P, Azoulay D, Feray C, et al. [Pneumocystis carinii and cytomegalovirus pneumonia after corticosteroid therapy in acute severe alcoholic hepatitis: 2 case reports]. Gastroenterol Clin Biol 2002;26:532-534.

50. Faria LC, Ichai P, Saliba F, et al. Pneumocystis pneumonia: an opportunistic infection occurring in patients with severe alcoholic hepatitis. Eur J Gastroenterol Hepatol 2008;20:26-28.

51. Ikawa H, Hayashi Y, Ohbayashi C, Tankawa H, Itoh H. Autopsy case of alcoholic hepatitis and cirrhosis treated with corticosteroids and affected by Pneumocystis carinii and cytomegalovirus pneumonia. Pathol Int 2001;51:629-632.

52. Lahmer T, Messer M, Schwerdtfeger C, et al. Invasive mycosis in medical intensive care unit patients with severe alcoholic hepatitis. Mycopathologia 2014;177:193-197.

53. Rosman AS, Waraich A, Galvin K, Casiano J, Paronetto F, Lieber CS. Alcoholism is associated with hepatitis C but not hepatitis B in an urban population. Am J Gastroenterol 1996;91:498-505.

54. Shoreibah M, Anand BS, Singal AK. Alcoholic hepatitis and concomitant hepatitis C virus infection. World J Gastroenterol 2014;20:11929-11934.

55. Singal AK, Kuo YF, Anand BS. Hepatitis C virus infection in alcoholic hepatitis: prevalence patterns and impact on in-hospital mortality. Eur J Gastroenterol Hepatol 2012;24:1178-1184.

56. Singal AK, Sagi S, Kuo YF, Weinman S. Impact of hepatitis C virus infection on the course and outcome of patients with acute alcoholic hepatitis. Eur J Gastroenterol Hepatol 2011;23:204-209.

57. Singal AK, Salameh H, Singal A, et al. Management practices of hepatitis C virus infected alcoholic hepatitis patients: A survey of physicians. World J Gastrointest Pharmacol Ther 2013;4:16-22.

58. Hoofnagle JH, Davis GL, Pappas SC, et al. A short course of prednisolone in chronic type $\mathrm{B}$ hepatitis. Report of a randomized, double-blind, placebo-controlled trial. Ann Intern Med 1986;104:12-17.

59. Di Bisceglie AM, Lok AS, Martin P, Terrault N, Perrillo RP, Hoofnagle JH. Recent US Food and Drug Administration warnings on hepatitis $B$ reactivation with immune-suppressing and anticancer drugs: just the tip of the iceberg? Hepatology 2015;61:703-711.

60. Kumar Acharya S, Kumar Sharma P, Singh R, et al. Hepatitis E virus (HEV) infection in patients with cirrhosis is associated with rapid decompensation and death. J Hepatol 2007;46:387-394.

61. Rudler M, Thibault V, Mouri S, et al. Hepatitis E infection in patients with severe alcoholic hepatitis: is there a place for systematic screening? Eur J Gastroenterol Hepatol 2015;27:1367-1371.

62. Pol S, Durand F, Bernuau J, et al. Herpesvirus infection of the respiratory tract in patients with alcoholic hepatitis. Alcohol Clin Exp Res 1992;16:979-981.

63. Caldwell JE, Porter DD. Herpetic pneumonia in alcoholic hepatitis. JAMA 1971;217:1703. 